\title{
Research on cooperative learning strategy in oral English teaching of college students
}

\author{
Hongbin LI \\ Foreign Language Department of Jilin Business and Technology College \\ Changchun City, China, \\ Email:lihongbin1975@163.com
}

\begin{abstract}
-cooperative learning is an innovative teaching strategy. Numerous studies have shown that oral English teaching from the perspective of cooperative learning can improve classroom atmosphere and provide the opportunity to for students to speak English. Therefore, in the process of implementation of oral English teaching in colleges, English should be seen as a communication tool. Team cooperation can realize teaching and learning so as to cultivate the students to speak English. Starting from the theoretical background of cooperative learning, this paper analyzes the factors that influence the oral English teaching and analyzes the concrete strategies in implementation of cooperative learning in college oral English teaching.
\end{abstract}

Keywords-college english; oral english teaching; cooperative learning

As our country's economic and cultural development is becoming faster and faster currently, the national overall quality requirements are also rising, as a matter of course, the traditional education mode of college English begins to change from talent education towards quality education. Most of the English teaching classes in China belong to large-scale class teaching, so, there are quite a large number of middle school students in each class, resulting in a decline in the average resource of education, which is obvious in schools in remote areas, whose deficiency in facilities shortage and staff disqualification gives rise to the serious influence on teaching quality of oral English, so it is necessary to introduce the cooperative learning in oral English teaching of college.

\section{ThE BASIC MEANING AND RELATED THEORIES OF COOPERATIVE LEARNING}

Cooperative learning is actually a kind of old education concept. As early as two thousand years ago, Records of Education, the Chinese ancient education classics, pointed out "those who learn alone without friends will be ignorant and ill-formed", emphasizing the significance of cooperation in the learning process. As a kind of education concept and teaching method, cooperative learning theory arose in the United States in the 1970s. The following is a summary of several theories related to cooperative learning theory. ${ }^{[1]}$

First, the cognitive theory. the psychologist Sweller from Switzerland used to think that if students want to get progress, they must study with the help of a self adjusting balance process. So, to understand the behavior of the students' oral English learning, students must firstly understand how to deal with the relationship between themselves and the social environment, and take measures on the basis of cooperative learning to continuously adjust their cognitive conflicts existing in the oral English, and eventually improve their cognitive level. In addition, language has the characteristics of randomicity and sociality, therefore, it can be acquired and mastered only in the process of constant communication with others. So social cooperation helps the individual achieve the new cognitive balance with the assimilation of others. In addition, discourse between partners with similar cognitive level can stimulate individual cognitive development better than anyone else.

Second, language acquisition theories. There are generally two ways to master language: acquisition and learning. Acquisition needs learners in communication practice to realize the unconscious learning, absorb the language, and correctly and fluently use the language in the unconscious circumstance. Learning is to consciously understand the language in a rational way. ${ }^{[2]}$ English language knowledge mastered in the acquisition can be used to communicate freely and fluently with others. Therefore, in the process of language learning, acquisition is more important than learning.

Third, the education theory of interactive development. Under the background of this theory, it can promote students to master related concepts in oral English teaching class to the largest extent to set appropriate learning tasks through the way of cooperation learning. High-quality interactive activities, for example, interaction guided by the other students, is very important to ascension of English level.

Through the review of Chinese and foreign scholars' understanding of cooperative learning, cooperative learning is a kind of teaching activity taking group as the main body, which focuses on a clear learning objective, high cohesion, efficient learning, interaction and mutual aid. In addition, the overall performance of the whole team can be seen as a basis to evaluate and reward students. 


\section{INFLUENCE FACTOR ANALYSIS OF ORAL ENGLISH TEACHING IN THE CONTEMPORARY COLLEGES}

First of all, the lack of an effective English language atmosphere. Students in most schools are in a pure Chinese teaching environment to learn English. Weekly English course is arranged in a low frequency, in addition, students have less chance to learn English after class. The interaction between students is mainly Chinese. These factors all cause great influence on the development of students' ability of spoken English, especially the language application ability.

Second, most students lack of confidence as well as ability to talk with others in English. The lack of regular training of spoken English and students' insufficiency in English vocabulary cause students embarrassed to speak English in public. At the same time, students are afraid of poor oral English in the presence of others or miscommunication with spoken English, many students hardly participate in the activities of spoken English for fear of becoming a laughing stock in class. All these factors severely dampen the enthusiasm of students to use English to communicate. ${ }^{[3]}$

Finally, the large number of students in the class. As is known, language is the most important social communication tool and people achieve mutual understanding through language communication. Each language needs to be learned in a specific atmosphere. However, in the English classes of colleges, there are quite a great number of students in each class, which makes it difficult to to take oral training in English classroom teaching, as a matter of course, mutual activities between teachers and students are limited, no speaking of oral English practice. Sometimes, teachers, in order to pursue the teaching schedule, ignore the oral English learning and practice of the whole class or even save this process directly, as a result, it needn't go to the details of students' oral English.

\section{CONCRETE IMPLEMENTATION OF COOPERATIVE LEARNING IN COLLEGE ORAL ENGLISH TEACHING}

\section{A. Design reasonable grouping of students}

In order to better carry out cooperative learning in the teaching activities, at the beginning of class, English teachers should take students' academic performance, personality, ability and other factors into consideration, according to the principle of homogeneity in the group and heterogeneity between groups, to carry on a reasonable grouping of students, in which the outstanding students are matched to the unqualified students and the outgoing students are matched to the introverted students. In terms of this, English teachers can take four students to form a group and arrange seats for students after proper grouping so as to facilitate team members in daily communication. Students can play various roles in their team and be responsible for different activities, such as organization, recording, data collection, reporting and evaluation etc.

In terms of group assignment, scene dialogue and performing tasks can be arranged in advance. English teachers require that all students must be involved into group discussion, then, according to the study topic, design characters and lines, making all students get the opportunity to express themselves. In other types of oral English teaching activities such as view discussion and expression, teachers can randomly make any student as a representative in each group to speak English on behalf of the other members. Through cooperative learning activities, all the students can be familiar with the class topic and express their view freely and fluently.

\section{B. Design a challenging task of cooperation}

Once the task designed for any group is too difficult, it will easily dampen students' self-confidence, on the other hand, if the learning task is too easy, it is not conducive to the improvement of cooperative learning. So, in the design of cooperative learning teaching task, it needs to accord with most of the students' oral English ability, at the same time, the cooperative learning teaching task should also have characteristics of practicality, flexibility and challenging. Only in this way can it stimulate students' thirst for knowledge and curiosity for learning oral English, and through this process, it can fully improve the satisfaction of spoken English learning with a sense of achievement.

\section{Teachers should play a leading role}

In oral English teaching, teachers should not only have profound professional knowledge, but also get rid of the stale and bring forth the fresh, freely use English text books on basis of the implementation of cooperative teaching and have the flexibility and ability to organize oral English teaching activities of English class. In order to achieve this, English teachers should be adopt various creative teaching methods flexibly. In the process of practical teaching, English teachers should rapidly change their tradition view of oral English teaching, play a leading role in cooperative learning, and guide students to explore problems and solutions in oral English learning.

Second, they should also control the learning process of each group, independently providing students with the required materials associated with oral English learning activities. Finally, in the cooperative learning activities, English teachers need to fully excavate students' oral English learning potential and pay attention to the cultivation of students' cooperative learning concept and positive learning attitude. In addition, teachers should also change the concept of unified teaching in traditional classroom teaching and build a relaxing and harmonious learning atmosphere for students. In cooperative learning, teachers should respect students' personality and development of individuality, keep fair attitude for all the students, and scientifically treat students' language mistakes in English class, in this way, students with a fear and anxiety in oral English class can overcome their bashfulness and take the initiative to actively participate in oral English communication. 


\section{Enrich the evaluation form of students' cooperative learning}

In class, English teachers should evaluate the result of group cooperative learning through a variety of forms. Group performance can be evaluated according to the article content, group performance, storytelling, picture description, talk and discuss. On the oral topic of "the generation gap", for example, in the oral English teaching, English teachers can let the students design team performance situation in advance and present the scene vividly and incisively in which students have a serious conflict with parents and can't understand each other. What's more, English teachers can let their students use the words and phrases in the article to make up a short story, thus, oral English teaching under the guidance of cooperative learning can be evaluated through interviews, playing games and debation. ${ }^{[4]}$ Finally, English teachers should to positively affirm students according to group performance and reward the outstanding students.

\section{CONCLUSION}

Cooperative learning in college oral English teaching is a kind of effective oral English teaching form and teaching strategy, which can improve the classroom atmosphere, provides students with the opportunity to speak English to a large extent. However, because the domestic researches on cooperative learning in college oral English teaching are still in great infancy in the current, what's worse, theoretical study is not enough and practice in classroom teaching is not mature, education workers and experts have a lot of work to do in such circumstance. On the basis of education theories, such as social psychology, cognitive psychology and sociology and in combination with the practice of cooperative learning in college oral English teaching, a more creative and effective teaching mode can be further improved.

\section{REFERENCE}

[1] Johnson,Karen E . Understanding Communication in Second Language Classrooms[M] . The Press of the University of Cambridge, 2000

[2] Kathleen M. Baile. Oral English Teaching and Research[M].Higher Education Press ,2007

[3] Zhang Xun. The organization strategy and theory of cooperative learning in oral English classroom[J]. Foreign Languages and Their Teaching, 2007

[4] Liu Qin. Chinese college students' oral English level[J]Modern Foreign Languages, 2008 